\title{
Unusual mucoepidermoid carcinoma of the liver misdiagnosed as squamous cell carcinoma by intraoperative histological examination
}

\author{
Xiao-qin Guo ${ }^{1}$, Bin Li ${ }^{1}$, Yang $\mathrm{Li}^{1}$, Xiao-ying $\operatorname{Tian}^{2}$ and $Z \mathrm{Zhi}_{\mathrm{Li}}{ }^{\text {* }}$
}

\begin{abstract}
As rare condition, mucoepidermoid carcinoma may occur in liver although its etiology and pathogenesis is still unclear. We report here a case of intrahepatic mucoepidermoid carcinoma misdiagnosed as cholangiocarcinoma and squamous cell carcinoma by preoperative radiologic and intraoperative histological examinations, respectively. A 60-year-old woman presented with a 1-month history of progressive jaundice, epigastric discomfort, and weight loss with slightly increased carbohydrate antigen 19-9 (CA19-9). Computed tomography (CT) showed a large tumor, $8.0 \mathrm{~cm}$ in diameter, in the left lobe of the liver. A preliminary diagnosis of a cholangiocarcinoma of the liver was made. In the intraoperative histological examination, a diagnosis of squamous cell carcinoma was made based on predominantly invasive epidermoid cells with abundant keratinization and absence of mucin-producing cell component. However, postoperative histological diagnosis of the lesion was mucoepidermiod carcinoma of liver by thoroughly microscopical inspection and the presence of mucin-producing cells confirmed by Alcian blue staining. Despite surgical excision and chemotherapy, the tumor showed very aggressive malignancy with tumor recurrence. The patient died shortly afterward, surviving 6 months after surgery. Due to its rarity and distinct morphological features, mucoepidermoid carcinoma might be erroneously interpreted as squamous cell carcinoma by those who were not familiar with this condition in unusual locations. Therefore, removal of sufficient tissue from different portions of the lesion is essential for the surgeons and pathologists to make a precise diagnosis in the intraoperative histological examination.
\end{abstract}

Virtual slide: The virtual slide(s) for this article can be found here: http://www.diagnosticpathology.diagnomx.eu/vs/ 4956311271136060

Keywords: Mucoepidermoid carcinoma, Intrahepatic tumor, Histological features, Differential diagnosis

\section{Background}

Mucoepidermoid carcinoma is a relatively common neoplasm of the salivary glands, which rarely arises in other sites, including esophagus, anal canal, skin of the breast, lachrymal sac, thymus, thyroid gland, lung or uterine cervix [1-4]. Primary intrahepatic mucoepidermoid carcinoma is rare tumor with only 17 cases described in the English literature so far [5-17]. Because of its relative rarity in liver, its etiology has not yet been elucidated. Terminal intrahepatic bile ducts or biliary congenital cysts have been proposed as a possible origin $[5,7,8,11]$. Histologically,

\footnotetext{
* Correspondence: lizhi@mail.sysu.edu.cn

'Department of Pathology, The First Affiliated Hospital, Sun Yat-sen

University, 58, Zhongshan Road II, Guangzhou 510080, China

Full list of author information is available at the end of the article
}

mucoepidermoid carcinoma is characterized by squamoid (epidermoid), mucus producing and cells of intermediate type. The proportion of different cell types and their architectural configuration varies in and between tumors. In general, it is not difficult to distinguish mucoepidermoid carcinoma from other tumors arising from salivary glands by histopathological examination because of its distinct triphasic cellular morphology. However, mucoepidermoid carcinoma can be confused with squamous cell carcinoma when intermediate cells and epidermoid sometimes are prominent in the tumor. In particular, when the mucoepidermoid carcinoma occurs in an unusual site, a definite diagnosis might not be obtained without carefully histological examination. We present a case of mucoepidermoid carcinoma occurring in an old female patient that was 
misdiagnosed as cholangiocarcinoma and squamous cell carcinoma by both radiologic and intraoperative histopathological examination, respectively.

\section{Case presentation}

A 60-year-old Chinese woman, presented with a history of progressive jaundice, epigastric discomfort, anorexia, malaise, and weight loss for 1 month. She had no remarkable medical or family history and had not had viral hepatitis. Clinical examination revealed a deeply jaundiced, emaciated woman without ascites. A hard, irregular liver was palpable $4 \mathrm{~cm}$ below the xiphisternum. The results of relevant laboratory studies were as follows: total protein, $7.6 \mathrm{~g} / \mathrm{dl}$; albumin, $3.5 \mathrm{~g} / \mathrm{dl}$; total bilirubin, $513 \mathrm{u} \mathrm{mol} / \mathrm{L}$; GOT, 35U; and GPT, 23U. $\alpha$-Fetoprotein (AFP) and carcinoembryonic antigen (CEA) were within the normal range and carbohydrate antigen 19-9 (CA19-9) was slightly increased to $50 \mathrm{mg} / \mathrm{dl}$ (normal range, 0-37 mg/dl). Hepatitis $B$ viral antigen and hepatitis $C$ antibody assays were negative. Abdominal ultrasound and abdominal computed tomography (CT) both showed a large liver tumor lesion, $8 \mathrm{~cm}$ in diameter involving the left lobe of the liver with intrahepatic bile duct stone (Figure 1). Therefore, a preliminary diagnosis of a cholangiocarcinoma of the liver was made, and the patient underwent left hepatic lobectomy with regional lymph node dissection. Intraoperative finding revealed an elastic hard tumor was found in the left lobe of the liver. The cut surface of the resected specimen showed an irregular, yellowish white solid tumor, measuring $8.5 \times$ $6.5 \times 3.0 \mathrm{~cm}$, with central necrosis. The border between the tumor and normal liver tissue was indistinct (Figure 2A). A piece of tumor tissue was resected from the surface for intraoperative histological examination. Microscopically, the tumor was predominantly composed of nests of invasive epidermoid cells. Most of the tumor cells were epidermoid with intercellular bridges and keratinization. There were no distinct mucin-producing cells in the tissues (Figure 2B).
Based on these findings, the diagnosis of squamous cell carcinoma of liver was made. The mass was totally removed.

\section{Pathological findings}

After surgery, routine histological investigation was performed on the removed mass. Histopathological examination revealed that the main tumor was composed of solid and invasive nests of epidermoid cells with desmoplastic stroma. However, in some areas, not only squamous cells, but also mucin-producing and intermediate cells were observed in the tumor. These tumor cells were intermingled or intimately mixed with epidermoid cells, unlike adenosquamous carcinoma. Mucin-producing cells were cuboidal, columnar, or goblet-like. There was extensive necrosis accompanied by neural invasion, lymphatic and blood vessel invasion. Mitotic figures were frequent and there was remarkable cellular pleomorphism. There were several hepatic hilar lymph nodes metastasis found. Immunohistochemically, the epidermoid cells of the tumor were positive to pan-cytokeratin (CK), CK5/6 and p63, but mucin-producing cells were negative to CK5/6 and p63. Alcian blue staining revealed mucin in the cytoplasm of the mucinproducing cells. Based on these findings, the final diagnosis of tumor was revised as mucoepidermoid carcinoma (Figure 3). The histological grading of the tumor was evaluated according to the neural invasion, necrosis, mitotic rate and degree of maturation of cellular components [18]. The tumor was graded as high grade. The patient had an uneventful postoperative recovery. Since there was a possibility of tumor metastasis to another anatomical location, the patient was referred to a whole body positron emission tomography (PET)/CT study to search for the potentially secondary tumor, but no abnormality was found. After diagnosis, the patient received chemotherapy with gemcitabine, 5-fluorouracil and cisplatin. However, two months later she was admitted into another hospital with recurrent liver disease. She died shortly afterward, surviving 6 months after surgery. No postmortem was performed.

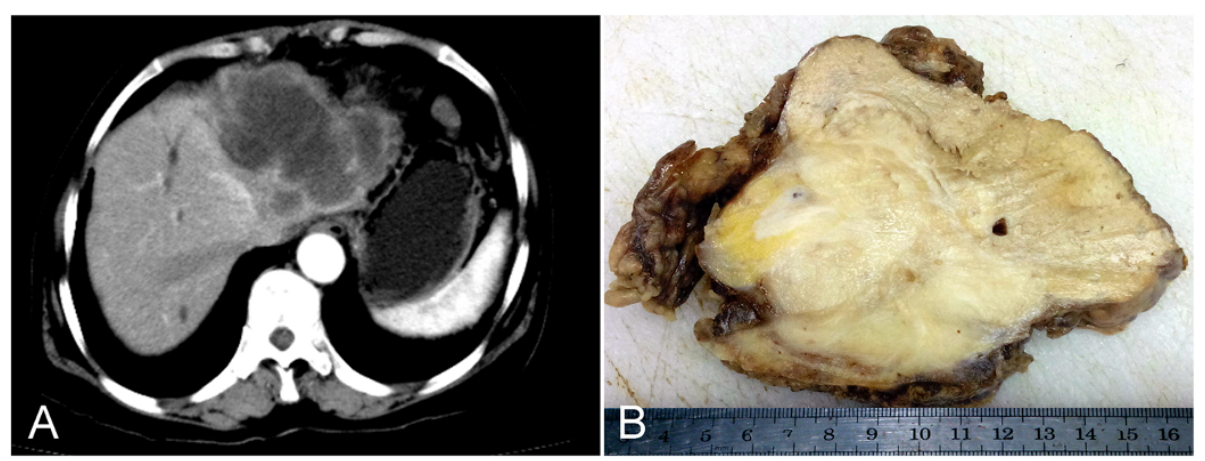

Figure 1 Preoperative and gross findings of tumor. (A) Computed tomography (CT) showed a large tumor lesion, $8.0 \mathrm{~cm}$ in diameter, in the left lobe of the liver. (B) Gross examination of resected liver mass showed an irregular, yellowish white solid tumor without a fibrous capsule. The border between the tumor and normal liver tissue was indistinct. 


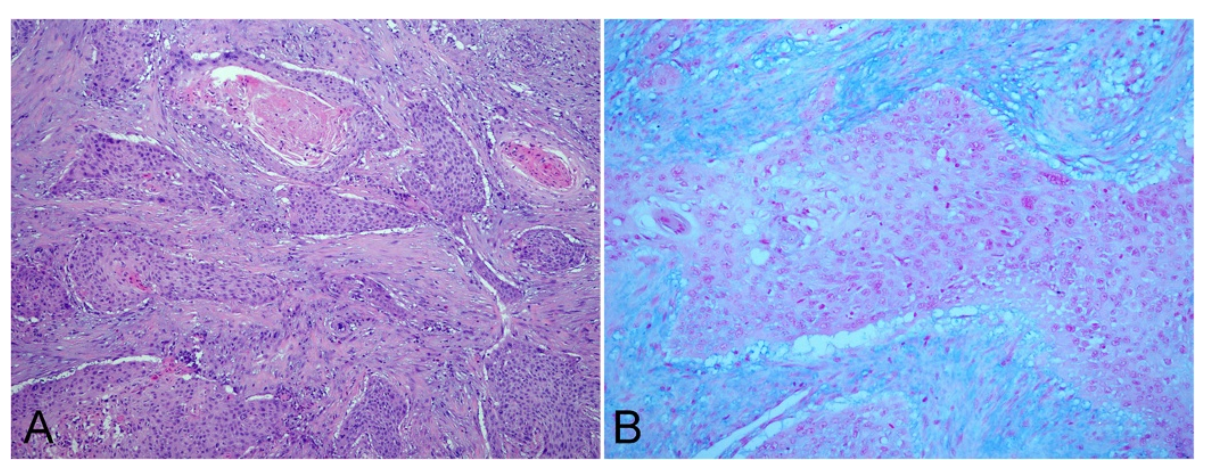

Figure 2 Micrographs of liver mass in intraoperative histological examination. (A) Intraoperative tumor tissue showed the tumor mass was predominantly composed of solid and invasive nests of epidermoid cells with abundant keratinization in desmoplastic stroma. (B) Alcian blue staining showed that there was no mucin-producing cells intermingled within the epidermoid cells nest. (A, HE staining with original magnification $\times 400$; B, Alcian blue staining with original magnification $\times 400)$.

\section{Discussion}

Mucoepidermoid carcinoma of liver is rare. In 1971, Pianzola and Drut reported the first case and suggested that this type of carcinoma arose from the terminal ramifications of bile canaliculi in association with squamous metaplasia [5]. However, the etiology and pathogenesis of mucoepidermoid carcinoma of the liver is still unclear. Some authors observed the remarkable neoplastic transformation of the normal duct lining epithelium, which suggested a possible of bile duct origination [16]. Some authors proposed that mucoepidermoid carcinoma of the liver might originate from a congenital cyst because the main tumors were located in the vicinity of multiple seromucinous cysts lined with columnar, cuboidal glandular epithelium with no connection to the biliary system and no bile content $[8,11]$. The electron micrographs revealed tonofilaments and confirmed the squamous nature of the tumor cells. Immunohistochemical analysis provided evidence of the ductal epithelial origin of this neoplasm with consistently positive for CK7 and negative for CK20. Therefore, the World Health Organization (WHO) accepted the designation of mucoepidermoid carcinoma of liver as a rare but distinct variant of intrahepatic cholangiocarcinoma [19]. It is speculated that the lining epithelia of the congenital cysts in the liver may be transformed into the pluripotential intermediate cells, which may differentiate into both mucus-secreting and squamous cells.

Despite its enigmatic histogenesis, the pathological diagnosis of mucoepidermoid carcinoma of liver is based on both mucin-producing and epidermoid malignant cells in intimately mixed nests [18]. But establishing a preoperative diagnosis is difficult because of the rarity of these tumors and the fact that there are no specific landmarks in the radiologic examinations. Conventional CT and ultrasonography usually show an intrahepatic mass and make the diagnosis of intrahepatic cholangiocarcinoma or hepatocellular carcinoma. Like the most of previously reported cases, the current case was diagnosed as intrahepatic cholangiocarcinoma in the preliminary radiologic examination. In intraoperative investigation, the tumor was predominantly composed of nests of invasive epidermoid cells in desmoplastic stroma without distinct mucin-producing cells component. Furthermore, most of the tumor cells were epidermoid with intercellular bridges and keratinization, which might be regarded as keratinizing pearl of tumor, gave the histological appearance of squamous cell carcinoma. Since the mucoepidermoid carcinoma is rare in liver, these morphological features might be erroneously interpreted squamous cell carcinoma by those who were not familiar with this condition. This might be the reason that led to the misdiagnosis of squamous cell carcinoma. In our case, it was difficult for pathologists to provide a precise diagnosis from a few very small tumor tissues in the intraoperative histological investigation. However, in routine histological examination, correct diagnosis was gained by thorough inspection and presence of mucin-producing cells component. Therefore, surgeons should be responsible for removing sufficient tumor tissue from different portions of the tumor even if the first specimen supports the radiologic diagnosis.

To our knowledge, only 17 cases of primary mucoepidermoid carcinoma of the liver have been described in the literature so far [5-17] (Table 1). The ratio of mucoepidermoid carcinoma of liver incidence in women and men is $8: 9$, which is different from this tumor occurring in salivary gland with a 3:2 female predilection. Intrahepatic mucoepidermoid carcinoma seems to occur frequently in elderly patients (ranged from 35 to 81 years with mean age of 60), although its counterpart in salivary gland occur most commonly in patients under 40 years old [18]. 11 of 17 cases had lymph nodes and (or) distant metastasis and 15 patients died of disease within 7 days to 11 months after excision, although several cases received chemotherapy after surgical resection, including our case. In laboratory 


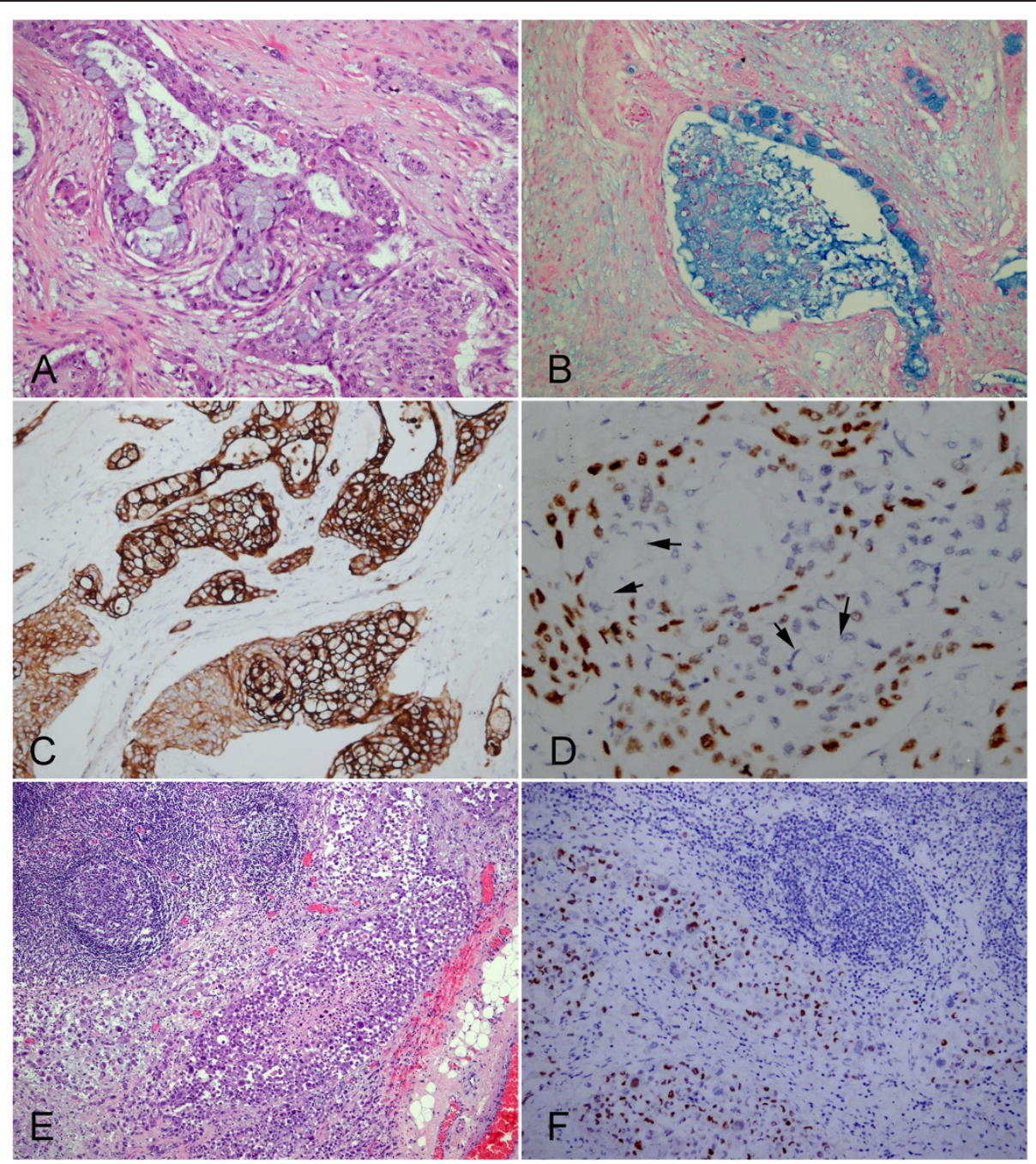

Figure 3 Postoperative micrographs of liver mass. (A) Postoperative histological examination of tumor exhibited that nests of malignant epidermoid cells were intimately mixed with mucus-producing cells. (B) The Alcian blue-positive material was seen in lumen of gland structure and the mucin-producing cells within the nest of epidermoid cells. (C) Tumor cells were diffusely positive for CK7. (D) The epidermoid cells were observed to be positive for p63, but the mucin-producing cells (black arrows) were p63-negative. (E) The lymph nodes metastasis of tumor was observed. (F) The metastatic tumor cells were also positive for p63 partially. (A and $\mathbf{E}$, HE staining with original magnification $\times 400$; $\mathbf{B}$, Alcian blue staining with original magnification $\times 400$; $\mathbf{C}, \mathbf{D}$ and $\mathbf{F}$, immunohistochemical staining with original magnification $\times 400$ ).

data, more than half the cases showed high CEA or CA199 with normal AFP and was diagnosed preoperatively as cholangiocarcinoma or hepatocellular carcinoma. Only one case showed elevated the tumor marker of squamous cell carcinoma, suggesting a squamous component [15]. However, none of previously reported cases was diagnosed as mucoepidermoid carcinoma of the liver preoperatively. That indicates diagnosing primary mucoepidermoid carcinoma in the liver is clinically difficult because these tumors are rare and have no specific findings by radiological and laboratory examinations. Therefore, percutaneous biopsy is needed for this tumor to obtain a definite diagnosis preoperatively [17].
Mucoepidermoid carcinomas arising in salivary gland and central airway of lung should be distinguished from other salivary gland-type tumors, such as adenoid cystic carcinoma, clear cell carcinoma, epithelial-myoepithelial carcinoma, and pleomorphic adenoma, especially in pediatric population $[20,21]$. Recent study has demonstrated that decreased expression of maspin (mammary serine protease inhibitor) and marked increase of MCM2 (minichromosome maintance-2) expression support the diagnosis of high-grade mucoepidermoid carcinoma [22]. However, due to their rarity and distinct morphological features, primary mucoepidermoid carcinoma of the liver is sometimes misdiagnosed as cholangiocarcinoma with squamous 
Table 1 Clinicopathological features of intrahepatic mucoepidermoid carcinoma described in present and previous reports

\begin{tabular}{|c|c|c|c|c|c|c|c|c|c|c|}
\hline No. & Authors (yr.) & $\begin{array}{l}\text { Age (year)/ } \\
\text { Gender }\end{array}$ & $\begin{array}{l}\text { Location/ } \\
\text { size }(\mathrm{cm})\end{array}$ & $\begin{array}{l}\text { Clinical } \\
\text { manifestation }\end{array}$ & $\begin{array}{l}\text { Tumor } \\
\text { markers }\end{array}$ & $\begin{array}{l}\text { Preoperative } \\
\text { diagnosis }\end{array}$ & Metastasis & $\begin{array}{l}\text { Histological } \\
\text { grading }\end{array}$ & Treatment & Outcome \\
\hline 1 & Pianzola LE [5] & $44 / M$ & $\mathrm{RL} / 15.0$ & Abdominal pain & NA & Hydatid cyst & None & NA & Surgical excision & $\begin{array}{l}\text { Liver failure and dead } 45 \text { days } \\
\text { after surgery }\end{array}$ \\
\hline 2 & Ho JC [6] & $65 / M$ & $\mathrm{RL} / 8.0$ & Jaundice & NA & NA & $\begin{array}{l}\text { Lymph node } \\
\text { and pancreas }\end{array}$ & NA & Conservative & $\begin{array}{l}\text { Complication and dead } 14 \text { days } \\
\text { after biopsy }\end{array}$ \\
\hline 3 & & $63 / F$ & LL/6.0 & Abdominal pain & NA & NA & $\begin{array}{l}\text { Lymph node } \\
\text { and pancreas }\end{array}$ & NA & Conservative & Dead 16 days after diagnosis \\
\hline 4 & Koo J [7] & $44 / F$ & $\mathrm{LL} / 12.0$ & $\begin{array}{l}\text { Cholangitis and } \\
\text { hepatomegaly }\end{array}$ & AFP $<5$ & $\mathrm{CC}$ & None & NA & $\begin{array}{l}\text { Surgical excision + } \\
\text { Chemotherapy }\end{array}$ & $\begin{array}{l}\text { Recurrence and dead } 6 \text { months } \\
\text { after surgery }\end{array}$ \\
\hline 5 & & $66 / M$ & $\mathrm{CHD} / 4.0$ & Progressive jaundice & AFP $<5$ & NA & Lymph node & NA & Surgical excision & Died 1 week after surgery \\
\hline 6 & & $62 / M$ & $\mathrm{CHD} / 1.5$ & Progressive jaundice & $\mathrm{APF}<5$ & NA & None & NA & Surgical excision & $\begin{array}{l}\text { Alive after } 10 \text { months } \\
\text { following-up }\end{array}$ \\
\hline 7 & Katsuda S [8] & $78 / \mathrm{M}$ & $\mathrm{LL} / 11.0$ & Hepatomegaly & $\mathrm{AFP}=12.5$ & $\mathrm{HCC}$ & $\begin{array}{l}\text { Lymph node } \\
\text { and lung, kidney }\end{array}$ & NA & Chemotherapy & Recurrence and dead 3 months \\
\hline 8 & Kim YI [9] & $35 / M$ & $\mathrm{LL} / 18.0$ & Abdominal pain & AFP $<5$ & NA & None & NA & Surgical excision & Alive after 1 year following-up \\
\hline 9 & Lambrianides AL [10] & $59 / F$ & $\mathrm{RL} / 18.0$ & Abdominal pain & NA & SCC & Kidney & NA & Conservative & Dead 14 days after diagnosis \\
\hline 10 & Hayashi I [11] & $46 / F$ & $\mathrm{LL} / 3.0$ & Abdominal pain & AFP $=20$ & NA & None & High-grade & Surgical excision & $\begin{array}{l}\text { Recurrence and dead } 11 \text { months } \\
\text { after surgery }\end{array}$ \\
\hline 11 & Di Palma S [12] & $66 / F$ & LL/9.5 & Abdominal pain & $C A 19-9=500, C E A<2$ & NA & $\begin{array}{l}\text { Diaphragm and } \\
\text { pericardial }\end{array}$ & High-grade & Surgical excision & $\begin{array}{l}\text { Whole body metastasis and } \\
\text { dead } 6 \text { months after surgery }\end{array}$ \\
\hline 12 & Kim JM [13] & $68 / M$ & $\mathrm{LL} / 10.0$ & NA & AFP $<5$ & NA & None & NA & Conservative & NA \\
\hline 13 & Shuangshoti S Jr [14] & $64 / M$ & $\mathrm{LL} / 5.0$ & Jaundice & NA & NA & Lymph node & High-grade & Conservative & $\begin{array}{l}\text { Intestinal bleeding and dead } \\
7 \text { days after diagnosis }\end{array}$ \\
\hline 14 & Kang H [15] & $52 / \mathrm{M}$ & $\mathrm{LL} / 7.0$ & Epigastric pain & $\mathrm{AFP}<5, \mathrm{SCC}=14.1$ & $\mathrm{HCC}$ & Lymph node & High-grade & Surgical excision & Dead 6 month after surgery \\
\hline 15 & Choi D [16] & $69 / F$ & $\mathrm{RL} / 16.0$ & Abdominal pain & $C A 19-9=240$ & Liver abscess & Diaphragm & NA & Surgical excision & $\begin{array}{l}\text { Recurrence and dead } 4 \text { months } \\
\text { after surgery }\end{array}$ \\
\hline 16 & Arakawa Y [17] & $81 / F$ & $\mathrm{RL} / 10.0$ & Fever & CA19-9 = 14893 & $\mathrm{CC}$ & Lymph node & High-grade & Chemotherapy & $\begin{array}{l}\text { Cholangitis and dead } 4 \text { months } \\
\text { after diagnosis }\end{array}$ \\
\hline 17 & The present case & $60 / F$ & $\mathrm{LL} / 8.5$ & $\begin{array}{l}\text { Jaundice and } \\
\text { epigastric pain }\end{array}$ & $C A 19-9=50$ & $\mathrm{CC}$ & Lymph node & High-grade & $\begin{array}{l}\text { Surgical excision + } \\
\text { chemotherapy }\end{array}$ & $\begin{array}{l}\text { Recurrence and dead } 6 \text { months } \\
\text { after surgery }\end{array}$ \\
\hline
\end{tabular}

M, male; F, female; RL, right lobe of liver; LL, left lobe of liver; CHD, common hepatic duct; AFP, a-fetoprotein; CA19-9, carbohydrate antigen 19-9; CEA, carcinoembryonic antigen; CC, cholangiocarcinoma; HCC, hepatocellular carcinoma; SCC, squamous cell carcinoma; NA, not available. 
metaplasia, adenosquamous carcinoma or squamous cell carcinoma because the proportion of different cell types and their architectural configuration varies in and between tumors. Higuchi et al. emphasized the importance of differential diagnosis for adenosquamous carcinoma, adenoacanthoma, and mucoepidermoid carcinoma when they occurred in liver [23]. In the present case, the epidermoid cell population and keratinization were prominent in the tumor, which might be erroneously interpreted as squamous cell carcinoma. However, mucin-producing cell is absent in the squamous cell carcinoma, which can be demonstrated in majority of tumor by Alcian blue and diastase-PAS staining. Sufficient tissue from different parts of the tumor and thorough inspection to find the mucinproducing cells will facilitate the precise diagnosis of mucoepidermoid carcinoma. Adenosquamous carcinoma combines an adenocarcinoma and squamous cell carcinoma. Unlike mucoepidermoid carcinoma, the two components of adenosquamous carcinoma show either as separate areas within the tumor or admixed. However, mucinsecreting cells were observed to intermingle or intimately mixed with epidermoid cells in mucoepidermoid carcinoma. In rare condition, cholangiocarcinomas containing discrete foci of benign-appearing squamous metaplasia are termed adenocarcinoma with squamous differentiation or adenoacanthoma, which might be confused with mucoepidermoid carcinoma or adenosquamous carcinoma. But the absence of mucin-secreting cells within the foci of squamous metaplasia will help to distinguish this tumor from with mucoepidermoid carcinoma.

Mucoepidermoid carcinoma of the liver is regarded as an aggressive tumor with poor prognosis despite surgical treatment. Recent study suggested that aberrant expression of p53 and mdm-2 correlated with the high histological grade of the tumor and were associated with tumor behavior and local recurrence [24]. Among those reported cases, more than 10 patients died within 6 months after the initial diagnosis [5-8,10,12,14-17]. Our patient survived for only 6 months after aggressive surgical intervention and chemotherapy. The specific chemotherapy regimen for mucoepidermoid carcinoma of the liver has not yet been established. The reported chemotherapy regimens for intrahepatic mucoepidermoid carcinoma were based on the standards for it in salivary glands, including adriamycin/ mitomycin combination, methotrexate/fluorouracil combination, or ormitomycin as a single agent. Some researchers suggested that molecular targeted chemotherapy including an anti-HER2 or anti-epidermal growth factor (EGFR)based regimen might be the most promising strategy for treatment of salivary gland cancers [25-27]. However, the overexpression or gene amplification of HER2 in intrahepatic mucoepidermoid carcinoma has not been clarified yet, although it could be detected in up to one-third of patients with mucoepidermoid carcinoma in the salivary glands.
Therefore, researchers suggest multi-institutional studies are needed to clarify the histogenesis and biological behavior of primary mucoepidermoid carcinoma of the liver [16].

\section{Conclusion}

In conclusion, we reported an unusual case of intrahepatic mucoepidermoid carcinoma misdiagnosed as squamous cell carcinoma by intraoperative histological examination. Due to its rarity, mucoepidermoid carcinoma may be erroneously interpreted as squamous cell carcinoma when the epidermoid cell population and keratinization were prominent in the tumor. Therefore, more precise diagnosis for those rare cases in the intraoperative histological examination is facilitated by obtaining sufficient tissue from different parts of the lesion.

\section{Consent}

Written informed consent was obtained from the patient's family for publication of this case report and any accompanying images. A copy of the written consent is available for review by the Editor-in-Chief of this journal.

\section{Competing interests}

The authors declare that we have no competing interests.

\section{Authors' contributions}

XQG and BL made contributions to acquisition of clinical data, and analysis of the histological features by H\&E staining and immunoassays. They are joint first co-authors and made an equal contribution to this work. YL carries on the immunohistochemical and special staining. XYT drafted the manuscript. $Z \mathrm{~L}$ revised manuscript critically for important intellectual content and had given final approval of the version to be published. All authors read and approved the final manuscript

\section{Author details}

Department of Pathology, The First Affiliated Hospital, Sun Yat-sen University, 58, Zhongshan Road II, Guangzhou 510080, China. ${ }^{2}$ School of Chinese Medicine, Hong Kong Baptist University, 7, Baptist University Road, Kowloon Tong, Hong Kong, China.

Received: 18 November 2013 Accepted: 5 December 2013

Published: 29 January 2014

Reference

1. Singh A, Pandey KC, Pant NK: Cavitary mucoepidermoid carcinoma of lung with metastases in skeletal muscles as presenting features: a case report and review of the literature. J Cancer Res Ther 2010, 6:350-352.

2. Turkyilmaz A, Eroglu A, Gursan N: Mucoepidermoid carcinoma of the oesophagus: a case report. Acta Chir Belg 2009, 109:416-418.

3. Palermo MH, Pinto MB, Zanetti JS, Ribeiro-Silva A: Primary mucoepidermoid carcinoma of the breast: a case report with immunohistochemical analysis and comparison with salivary gland mucoepidermoid carcinomas. Pol J Pathol 2013, 64:210-215.

4. Nonaka D, Klimstra D, Rosai J: Thymic mucoepidermoid carcinomas: a clinicopathologic study of 10 cases and review of the literature. Am J Surg Pathol 2004, 28:1526-1531.

5. Pianzola LE, Drut R: Mucoepidermoid carcinoma of the liver. Am J Clin Pathol 1971, 56:758-761.

6. Ho JC: Two cases of mucoepidermoid carcinoma of the liver in Chinese. Pathology 1980, 12:123-128.

7. Koo J, Ho J, Wong J, Ong GB: Mucoepidermoid carcinoma of the bile duct. Ann Surg 1982, 196:140-148. 
8. Katsuda S, Nakanishi I, Kajikawa K, Takabatake S: Mucoepidermoid carcinoma of the liver. Acta Pathol Jpn 1984, 34:153-157.

9. Kim YI, Kim WH, Kim ST: Mucoepidermoid carcinoma: a variant of cholangiocarcinoma. Seoul J Med 1984, 25:256-259.

10. Lambrianides AL, Askew AR, Lefevre I: Thorotrast-associated mucoepidermoid carcinoma of the liver. Br J Radiol 1986, 59:791-792.

11. Hayashi I, Tomoda H, Tanimoto M, Furusawa M, Katsuda Y, Shirai S, Morimatsu M: Mucoepidermoid carcinoma arising from a preexisting cyst of the liver. J Surg Oncol 1987, 36:122-125.

12. Di Palma S, Andreola S, Audisio RA, Doci R, Lombardi L: Primary mucoepidermoid carcinoma of the liver. A case report. Tumori 1992 78:65-68.

13. Kim JM, Won JH, Kim JH: A case of mucoepidermoid carcinoma of the liver. Korean J Med 1994, 47:547-551.

14. Shuangshoti S Jr, Shuangshoti S: Primary mucoepidermoid carcinoma of the intrahepatic bile duct: a case report with review of literature. J Med Assoc Thai 2000, 83:197-203.

15. Kang H, Park YN, Kim SE, Sohn KR, Yoo NC, Park JY, Kim KS, Park C: Double primary mucoepidermoid carcinoma and hepatocellular carcinoma of the liver-a case report. Hepatogastroenterology 2003, 50:238-241.

16. Choi D, Kim H, Lee KS, Lee KG, Park CK: Mucoepidermoid carcinoma of the liver diagnosed as a liver abscess: report of a case. Surg Today 2004, 34:968-972.

17. Arakawa $\mathrm{Y}$, Shimada M, Ikegami T, Kubo T, Imura S, Morine $\mathrm{Y}$, Kanemura $\mathrm{H}$, Mori H: Mucoepidermoid carcinoma of the liver: report of a rare case and review of the literature. Hepatol Res 2008, 38:736-742.

18. Goode RK, El-Naggar AK: Mucoepidermoid Carcinoma. In World Health Organization Classification of Head and Neck Tumors. Edited by Barnes $L$, Eveson JW, Reichart P, Sidransky D. Lyon: IARC Press; 2005:219-220.

19. Nakanuma Y, Leong ASY, Sripa B, Ponchon T, Vatanasapt V, Ishak KG Intrahepatic Cholangiocarcinoma. In World Health Organization Classification of Tumors of the Digestive System. Edited by Hamilton SR, Aaltonen LA. Lyon: IARC Press; 2000:173-180.

20. Dalati T, Hussein MR: Juvenile pleomorphic adenoma of the cheek: a case report and review of literature. Diagn Pathol 2009, 4:32

21. Kayser K: Analytical Lung Pathology. Heidelberg: Springer-Verlag; 1992:256-257.

22. Abd-Elhamid ES, Elmalahy MH: Image cytometric analysis of $\mathrm{p} 53$ and mdm-2 expression in primary and recurrent mucoepidermoid carcinoma of parotid gland: immunohistochemical study. Diagn Pathol 2010, 5:72.

23. Higuchi T, Harada T, Okazaki M, Kikuchi M: Primary adenosquamous carcinoma of the liver. Aust N Z J Surg 1993, 63:319-323.

24. Ghazy SE, Helmy IM, Baghdadi HM: Maspin and MCM2 immunoprofiling in salivary gland carcinomas. Diagn Pathol 2011, 6:89.

25. Glisson B, Colevas AD, Haddad R, Krane J, El-Naggar A, Kies M, Costello R, Summey C, Arquette M, Langer C, Amrein PC, Posner M: HER2 expression in salivary gland carcinomas: dependence on histological subtype. Clin Cancer Res 2004, 10:944-946.

26. Haddad R, Colevas AD, Krane JF, Cooper D, Glisson B, Amrein PC, Weeks L, Costello R, Posner M: Herceptin in patients with advanced or metastatic salivary gland carcinomas. A phase II study. Oral Oncol 2003, 39:724-727.

27. Firwana B, Atassi B, Hasan R, Hasan N, Sukari A: Trastuzumab for Her2/ neu-positive metastatic salivary gland carcinoma: case report and review of the literature. Avicenna J Med 2012, 2:71-73.

doi:10.1186/1746-1596-9-24

Cite this article as: Guo et al:: Unusual mucoepidermoid carcinoma of the liver misdiagnosed as squamous cell carcinoma by intraoperative histological examination. Diagnostic Pathology 2014 9:24.

\section{Submit your next manuscript to BioMed Central and take full advantage of:}

- Convenient online submission

- Thorough peer review

- No space constraints or color figure charges

- Immediate publication on acceptance

- Inclusion in PubMed, CAS, Scopus and Google Scholar

- Research which is freely available for redistribution

Submit your manuscript at www.biomedcentral.com/submit
Ciomed Central 